\title{
Risk Factors And Impacts Of Sexually Transmitted Diseases Among Adult Females In Cairo
}

\author{
E. A. El-Moselhy; H. O. Khalifa ; K. M. Abd-Allah; F. A. Hassan*; R. B. \\ Atallah*; H. M. Hassan*; A. G. El-Darwish**; A. M. Ebrahim ***; \\ A. M. Osman ****; And M. A. Shatat***** \\ Departments of Community Medicine; Dermatology \& Venereology*; \\ Obstetrics \& Gynaecology **; Psychiatry ***; Microbiology ${ }^{* * * *}$ and Parasitology ${ }^{* * * * *}$ \\ Faculty of Medicine, Al-Azhar University.
}

\begin{abstract}
This study was conducted on ninety sexually transmitted disease (STD) adult female patients, attending Dermato-Venereology and Gynaecology Clinics, Al-Hussein University Hospital and an equal number of females as controls. The aim of the study was to determine sociodemographic, sexual and health care behaviours risk factors for STDs and to determine their impacts on the studied females. A retrospective, case-control, clinic based study was chosen to perform this research. Vaginal, cervical and urethral swabs and smears were taken. Also, scrapes from any suspicious lesions together with blood samples were taken from STD patients for various laboratory examinations. The most common STD was candidiasis (35.6\%). Shared house and unskilled occupations were the most important sociodemographic risk markers, odds ratio $(\mathrm{OR})=11.62$ and 2.92 , respectively. While, vaginal douche use and divorce were the most important gynaecological and reproductive risk factors, OR=7.16 and 4.06, respectively. Furthermore, premarital sexual practice and non-vaginal sexual practice were the most important sexual behaviours risk factors, $\mathrm{OR}=13.40$ and 10.97 , respectively. Also, previous infection with STDs and no partner referral were the most important health care behaviours risk factors, $\mathrm{OR}=6.45$ and 4.93 , respectively. Moreover, no religious obligation and drugs and/or alcohol use were the most important life style risk markers, OR=12.89 and 6.77, respectively. Lastly, history of pelvic inflammatory disease (18.9\%) and pregnancy wastage $(17.8 \%)$ were the most important impacts of STDs.
\end{abstract}

\section{Introduction}

Sexually transmitted diseases (STDs) are very common in most of the developing world and are among the most common causes of illnesses especially in women. However, its actual incidence is not known (Meheus and De Schryver, 1991). STDs are diseases that spread from person to another through intimate sexual contact. The reproductive tract is the most common site of infection, although, the mouth and anus may involved. There are more than 25 micro-organisms (bacteria, viruses, fungi, protozoa or arthropods) that can be sexually transmitted (Keersmaekers and Meheus, 1998 \& Gerbase et al., 1998). The appearance of the acquired immunodeficiency syndrome (AIDS), which is mainly STD, has led to change attitude to STDs problem (Meheus and De Chryver, 1991). The need for the control of STDs has become more urgent since they have been recognized as independent risk factors for the acquisition of AIDS (Richert et al., 1993 and Gertig et al., 1997). Moreover, some of STDs have been shown to increase the risk of transmission of AIDS by 24-fold (Laga et al., 1994 and Gerbase et al., 1998).

Political and economic conditions of the world may lead to situations that challenge the established balance between the social forces that spread STDs and those that limit their spread (Aral and Holms, 1999). In most of the world, the investment in public health development in general is 
poor. Activities that limit the spread of infectious diseases in the society are in the public health sector (Thurow, 1996). Sociodemographic and health care behaviours are important risk factors in STDs epidemiology. Predominance of young adults with the highest rate of sex partners results in an increase in commercial and casual sex. Poverty has an impact on migration and prostitution. Also, risk sex and health care behaviours as low condom use are important risk factors (Brunham \& Ronald, 1991; Brunham \& Embree, 1992; Keersmaekers \& Meheus, 1998 and Aral \& Holmes, 1999).

The growing recognition of the major role, STDs play in reproductive health, infertility, pregnancy outcome and perinatal infections has added a new dimension to the STDs problem (Mabey et al., 1985; Frost et al., 1987 and Wasserheit \& Holmes, 1992). The direct morbidity, the loss of economic productivity and long-term sequelae of STDs are equally important (Meheus and Keersmaekers, 1998). Complications, impacts and sequeale of STDs include: effect on pregnancy and the neonate (miscarriage, prematurity, congenital and neonatal infections, pelvic inflammatory disease (PID), ectopic pregnancy, infertility and cervical cancer (Braddick et al., 1991 and Wasserheit, 1992).

In Egypt, data indicate that STDs are major health and social problem. Health services focus mainly on clinical cure without any preventive activities. A study conducted in Giza, revealed high preval-ence of reproductive tract infections among rural women (WHO, 2001). Another study showed that $3.0 \%$ of women attending family planning clinics, $5.35 \%$ of drug users and $4.0 \%$ of women attending antena-tal care clinics had at least one STD (WHO, 2002).

Prostitution and promiscuous relations are strictly forbidden from the Holy Quran. The Holy Quran says: "And Come Not Nigh To Adultery, For It Is Shameful And Evil Opening The Road" (S 17, V 32).

The aim of this study is to determine the sociodemographic and sex and health care behaviours risk factors for adult female patients with STDs attending DermatoVenereology (DV) and Gynaecology
Clinics (Cs), Al-Hussein University Hospital and to determine the impact of STDs on them.

\section{Subjects And Methods}

Ninety adult female patients with clinical diagnosis of STDs attending DV and Gyaenecology Cs, Al-Hussein University Hospital and an equal number of females as controls, were enrolled in this study. Controls were selected from female patients attending these clinics for reasons other than STDs and genital tract complaints. Also, virgin females were excluded. Patients and controle were screened by a standerdized questiannaire (first et al., 1994) to excude psychiatic patients other than drug addicts. The entire control group were interviewed and examined, if any female of the control group had STD, she would be excluded. Both STD patients and controls were matched in age, their age range from 18 to 40 years. A retrospective, case-control, clinic based study was chosen to investigate this research problem. The purpose of the study and procedures to be performed were explained to both STD patients and controls. Informed consent of both of them was given. Patients and controls underwent a standardized complete pelvic examinations, speculum and bimanual. Attention was given to inflammation of the vulva, vagina and cervix, abnormal characteristics of vaginal discharge (increase amount, abnormal odour or yellow colour and consistency) and abnormal cervical, uterine and adnexal tenderness. Vaginal, cervical and urethral swabs were taken. Also, smears, swabs from any suspicious lesions together with blood samples were obtained from STD patients for various microbiological and serological investigations according to Brooks et al. (1998). Patients were routinely screened by microscopy for candidiasis, trichomoniasis, molluscum contagiosum and gonorrhoea, as well as for bacterial vaginosis. For patients with clinical diagnosis of cervical infection, microscopical examination for Gramstained smears of cervical discharge was done. Also, swabs of cervical discharge were immediately plated on Thayer Martin 
agar and incubated at $35^{\circ} \mathrm{C}$ in $5 \% \mathrm{CO}_{2}$ for gonorrhoea and on blood agar at $37^{\circ} \mathrm{C}$ for other bacterial pathogens. Growth on Thayer Martin agar was examined for Gram-negative dipliococci and fully identified by oxidase and sugar fermentation tests. While, growth on blood agar plates was identified by colonial morphology, Gram-stain, coagulase test, catalase test and ability to grow on a bile salt agar for Gram-positive cocci and sugar fermentation tests were performed for Gramnegative bacilli. Sera from patients with negative microscopical and culture results were examined for gonococcal antigens using ELISA technique. Lastly, cases of non-specific, non-bacterial cervicitis were examined for chlamydial infection by direct staining with flourescin-conjugated specific monoclonal antibodies. In cases of candediasis, direct Gram-stained smear was examined for Gram-positive budding yeasts of Candida albicans with further identification by culture on Sabaroud's agar and germ tube test. $\mathrm{T}$ vaginalis (TV) was detected by wet mount and/or by culture using in pouch TV. Bacterial vaginosis was detected by quantitative morphology of Gram stained slides based on Nugent's criteria (Nugent et al., 1991). In case of primary syphilis, diagnosis was done by dark field or phase-contrast examination of exudates of lesion. While, in case of secondary syphilis, diagnosis was done by serological test, the rapid plasma reagin test, positive test was confirmed by Treponema pallidum haemagglutination test.

Genital herpes (GH) was clinically diagnosed by characteristic vesicular lesions, either with or without erosion or ulceration. Also, genital warts (GW) and molluscum contagiosum (MC) were diagnosed clinically. Scabies and pediculosis were, also, diagnosed clinically. A positive past-history of sexual contact was a basic prerequisite to determine a sexually nature of transmission of these infestations. Scabies was confirmed microscopically by examination of scarped materials from infected areas of the skin (papules) according to Garcia and Bruckner (2001). As regard pediculosis pubis, pubic hair was carefully and closely examined by a hand lens to check for an infestation with adult lice or mites. In cases of PID, diagnosis was made when cervical, uterine and/or adnexal tenderness was present, and cervical mucopus was seen. Patient was considered infertile if she reported that she wanted child or more, was trying to conceive and had had unprotected intercourse for more than 1 year.

Lastly, both STD patients and control group were submitted to an interview to answer questions relevant to topic of the study. Odds ratio (OR) with $95 \%$ confidence interval (CI) or exact confidence limits (ECL) and chi-square $\left(\chi^{2}\right)$ were used as tests of significance. The significance level for $\chi^{2}$ was accepted if the P-value $\leq 0.05$.

\section{Results And Discussion}

In this study (table 1), $35.6 \%$ of our STD patients had pure fungal infection (candidiasis), $21.1 \%$ had viral infections (10.0\% GW, 6.7\% GH and 4.4\% MC), $16.6 \%$ had bacterial infections $(8.9 \% \mathrm{BV}$, $3.3 \%$ gonococcal cervicitis, $2.2 \%$ syphilis and $2.2 \%$ non-gonococcal cervicitis), $13.3 \%$ had parasitic infestations (10.0\% scabies and $3.3 \%$ pediculosis pubis) and $6.7 \%$ had mixed vaginitis (fungal and protozoal infections). Blankhart et al. (1999) and Garg et al. (2002) observed that $46.6 \%$ and $19.0 \%$ of their patients respectively had candidiasis. Oriel and Walker (1990) stated that genital warts are very common among sexually active people. Also, Csonka (1990) stated that scabies is a very common infectious disease, more prevalent among low socioeconomic population, as our patients, in presence of factors aiding, the spread of scabies as overcrowding, poor hygiene and sexual promiscuity. Also, these STDs could be considered non-STDs from patient's point of view, so, patients presented in clinic in big numbers with no fear of STDs stigma. As regard bacterial vaginosis, Blankhart et al. (1999); Behets et al. (2001); Claeys et al. (2001) and Garg et al. (2002) found that $29.1 \%, 53.0 \%, 32.5 \%$ and $41.0 \%$ of their patients respectively had bacterial vaginosis. Also, Blankhart et al. 
(1999); Behets et al. (2001); Claeys et al. (2001) and Garg et al. (2002) observed that $9.9 \%, 24.0 \%, 7.1 \%$ and $4.0 \%$ of their samples respectively had trichomoniasis. As regard gonorrhoea, Behets et al. (2001 and 2002) found high prevalence of gonococcal cervicitis, $13.0 \%$ and $17.0 \%$, respectively. While, Bogaerts et al. (2001); Claeys et al. (2001) and Clift et al. (2003) found that $0.5 \%, 2.8 \%$ and $4.0 \%$, respectively. These figures difference could be explained, the smallest figures $(0.5 \%$ and $2.8 \%$ ) were found among married and general population of females. While, the high figures could be attributed to differences between the two communities. Our figure was closed to Claeys et al. (2001). While, Esquivel et al. (2003) and Mak et al. (2005) demonstrated that $12.4 \%$ and $7.4 \%$ of their patients respectively had chlamydia; this high figure is accepted as it represents a serodiagnosis. Also, Behets et al. (2001) observed that $16.0 \%$ and $16.0 \%$ of their patients had gonococcal and chlamydial cervicitis, respectively. As regard syphilis, Blankhart et al. (1999); Behets et al. (2001); Bogaerts et al. (2001); Claeys et al. (2001) and Clift et al. (2003) found that $6.7 \%, 4.0 \%, 2.9 \%, 2.2 \%$ and $24.0 \%$ of their samples respectively had syphilis. The highest figure $(24.0 \%)$ could be accepted as the sample represent female sex workers. In Egypt, WHO (2001) stated that recent data show an increase in the incidence of syphilis. Also, we observed that $6.7 \%$ of our STD patients had genital herpes. This figure was smaller than these of Gottlieb et al. (2002); Xu et al. (2002) and Dan et al. (2003) who reported 52.0\%, $13.2 \%$ and $13.3 \%$, respectively. These high figures could be accepted as they represent seroprevalences.

As regard sociodemographic factors (table 2), $71.1 \%$ of our STD patients were illiterate or read and write (OR=1.94, 95\% CI: 1.04-3.63). This was agreed with Gottlieb et al. (2002) who showed that the lowest educational level group among their herpes simplex virus (HSV) had the highest risk $(\mathrm{OR}=1.8,95 \% \mathrm{CI}$ : 1.5-2.2). Also, we found that secondary and university educations were risk for acquiring STDs $(\mathrm{OR}=2.12$, 95\% CI: 0.54-8.66). While,
Gottlieb et al. (2002) reported that university education was protective for their group of HSV. Also, unskilled occupation was present among $80.0 \%$ and $57.8 \%$ of our STD patients and controls, respectively $(\mathrm{OR}=2.92,95 \%$ CI: 1.43-6.01). Collectively, we reported that $75.5 \%$ of our STD patients were belonging to low social class $(\mathrm{OR}=1.86$, 95\% CI: 0.99-3.50). Socioeconomic status had direct and indirect effects on health promotion and health services provision (Aral and Holmes, 1999). Our result was in consistent with Xu et al. (2002) who reported high prevalence of HSV among group belongs to below poverty index and among minorities. While, Gottlieb et al. (2002) did not found that risk as regard income, but, they found more prevalence of HSV among minorities $(\mathrm{OR}=2.1,95 \%$ CI: 1.8-2.5). Also, Amo et al. (2005) did not found risk as regard prevalence of STDs among minorities and migrants. Among low social class, poor standards of hygiene could be representing another possible non-sexually acquired aetiology of some STDs, such as candidiasis, trichomoniasis, scabies and pediculosis (Osoba, 1981). Lastly, we observed that shared house and water closet (WC), carried a risk marker for STDs acquisition $(\mathrm{OR}=11.62,95 \% \quad \mathrm{CI}: 5.48-25.11)$. The social conditions in most developing societies were already fueling the spread of STDs (Aral and Holmes, 1999). This could be explained, shared house had an effect on sexual mixing, family cannot exert a conservative influence on individual social (including sexual) behaviour (Gillmore et al., 1999). Also, shared house could be indicate on low social class and urbanization and again, resulted in an increase in commercial and non-commercial casual sex and spread of STDs (Meheus and De Schryver, 1991; Keersmaekers and Meheus, 1998; Lopez-Velez et al., 2003 and Amo et al., 2005). Also, shared WC, could indicate on cross infection (a non sexually acquired aetiology) for some STDs, as candidiasis and trichomoniasis.

In this study (table 3), our results revealed that unmarried women (formerly married, i.e., divorced and widow) were at risk for acquiring STDs $(\mathrm{OR}=4.13,95 \% \mathrm{CI}$ : 
1.90-9.10; 4.06, 95\% CI: $1.68-10.06$ and 2.39, 95\% CI: 0.64-9.64, respectively). Binson et al. (1993) reported a higher figure of unmarried, this perhaps due to small age of their group. While, our finding was confirmed by Aral \& Holmes (1999) and Abdullah et al. (2002), who considered unmarried status as a risk marker for STDs. We may suspect that married women had their own sexual partners (husbands). On the other hand, divorced and widow may engaged in casual relations. Regarding age at menarche <13 years, was found among $60.0 \%$ of our STD patients compared with $45.6 \%$ among controls $(\mathrm{OR}=1.79,95 \% \mathrm{CI}$ : 0.95-3.39). Berman and Hein (1999) stated that the average age at menarche has decreased. On the other hand, $25.6 \%$ of our STD patients found to be married before age 20 years, compared with $17.8 \%$ of controls $(\mathrm{OR}=1.95,95 \%$ CI: $0.73-4.24)$. Moreover, $23.3 \%$ of our STD patients married by age $\geq 26$ years compared with $24.4 \%$ among the controls $(\mathrm{OR}=0.94,95 \%$ CI: 0.45-1.97). Also, we cleared that $45.6 \%$ versus $32.2 \%$ of our STD patients and control group respectively had an interval $\geq 7$ year between initiating sexual practice and marriage $(\mathrm{OR}=1.76$, 95\% CI: 0.923.38). So, we can conclude that $>13$ years passed from age at sexual maturation tell age of marriage. Sociocultural and behavioural changes have combined with changes in developmental physiology of adolescents led to increase the risk of STDs (Berman and Hein, 1999). Also, Forrest (1993) agreed and stated that societal changes have resulted increases in the average age at which young women married. The interval between menarche and marriage has increased from 8 years to 14 . Also, we observed that age at first pregnancy $<20$ years and $\geq 26$ years were risk factors $(\mathrm{OR}=1.5,95 \%$ CI: $0.65-3.45$ and $1.75,95 \%$ CI: 0.84-3.66, respectively). Moreover, number of lifetime pregnancies, 0 and $\geq 3$ found to be risk factors for STDs acquisition $(\mathrm{OR}=2.12,95 \% \mathrm{CI}$ : $0.32-17.20$ and 1.59, 95\% CI: $0.82-3.10$, respectively). On the other hand, our results revealed that currently pregnant present protection $(\mathrm{OR}=0.35,95 \%$ CI: 0.10-1.11). This could be accepted, pregnancy tend to decrease sexual activities. Collectively, contraceptive using found to be a risk factor for STDs acquisition (OR=1.31, 95\% CI: 0.70- 2.45). In details, intra uterine device (IUD) and oral contraceptive users, found to have similar risk $(\mathrm{OR}=1.28$ and 1.10 , respectively). Kirkman and Chantler (1993) stated that contraceptives alter in various ways the risk for acquiring STDs. IUD increase the risk of lower tract infections, as trichomoniasis and syphilis. There is an accepted biological explanation, IUD facilitate infection by mechanical means. On the other hand, Evans et al. (1993) showed that IUDs had protective effect against chlamydial infection by enhancing local immunity, recognized as foreign body, or by reducing the epithelial surface susceptible to infection through accelerating squamous metaplasia of columnar epithelium. Again, Kirkman and Chantler (1993) cleared that hormonal contraceptive gives protection to upper genital tract but not to the cervix. Also, Kirkman and Chantler (1993); Shoubnikova et al. (1997) and Rizk et al. (2003) noticed a lower prevalence of bacterial vaginosis among oral contraceptive users. Lastly, vaginal douche use, found to be a risk factor for STDs $(\mathrm{OR}=7.16, \quad 95 \% \quad$ CI: 2.91-18.15). Our finding was agreed with Claudia et al. (2001) and Rizk et al. (2003) who reported $36.0 \%$ and $38.2 \%$ respectively, close to our figure, $41.1 \%$.

In this study (table 4) our results showed that $35.5 \%$ of our STD patients initiating sexual practice $\leq 20$ years old compared with $21.1 \%$ of the controls $(\mathrm{OR}=2.06,95 \% \mathrm{CI}: 1.01-4.24)$. This was in accordance with Hunt (1974); Zelnik \& Kantner's (1980); Laumann et al. (1992); Leigh et al. (1994); Centers for Disease Control and Prevention (1995); Aral \& Holmes (1999); Berman \& Hein (1999); Gottlieb et al. (2002); Xu et al. (2002) and Dimitry-Abraham et al. (2003). Hunt (1974); Leigh et al. (1994) and Centers for Disease Control and Prevention (1995) showed that age of first intercourse has steadily decreased. By age 14, only $3.0 \%$ of females were sexually experienced, by age $15,26.0 \%$ of females were sexually experienced, by age $18,56.0 \%$ of females 
were sexually experienced and by age 25 , about $66.6 \%$ of females were sexually experienced. Moreover, $94.0 \%$ of women ages 18 to 24 said that they had had vaginal intercourse (Laumann et al., 1992). These high figures could be explained, much of sexual relationships freedom in western countries and increase age of marriage. Furthermore, because of low marriage rate at these ages, most of this represents premarital sex (Gillmore et al., 1999). Also, we observed that $56.7 \%$ of STD patients had premarital sexual practice $(\mathrm{OR}=13.40$, 95\% CI: 5.46-34.10). The increase over time in premarital intercourse has been documented, this was confirmed by Zelnik and Kantner's (1980); Pratt et al. (1984) and Gillmore et al. (1999) who reported $44.1 \%$ to $51.5 \%$. So, changes in sexual behaviour have placed females at increased risk for STDs with the trend to earlier age at first intercourse occurring worldwide (Friedman, 1992). It should be expected that premarital sex in the US has increased (Forrest, 1993), 94.0\% of 18 to 24 years old American females had had sex (Laumann, 1994 and Aral \& Holmes, 1999). The rise in premarital sexual activities were enabled in part by the technological advances of birth control, by the development of the modern women's liberation movement and by the social conditions and ideologies that promoted later marriage, women's entry into the labour force and a high divorce rate. Continuing late age at first marriage and the recycling of divorced people back into dating at various times in their lives mean that sex outside of marriage is likely to continue long into the foreseeable. On the other hand, there is no indication that values about extramarital sex are becoming more permissive, so whatever nonmonogamy occurs will probably continue to be clandestine. The real problem female's pose, in terms, social and public health concerns, is their failure to protect themselves against unwanted pregnancy and STDs (Gillmore et al., 1999). Regarding sexual practice with symptomatic partner, $30.0 \%$ and $6.7 \%$ of our STD patients and controls respectively practiced with symptomatic sexual partners $(\mathrm{OR}=6.00,95 \%$ ECL: 2.23 18.69). Also, $26.7 \%$ and $3.3 \%$ of our STD patients and controls respectively were sexually practiced when they symptomatic (OR=10.55, 95\% ECL: 2.98-56.37). This could be explained, many contributing factors as low socioeconomic standard, lack of health information's, lack of access to health care and bad sexual behaviour practice. As regard type of sexual practice (table 4) we found that non-vaginal practice was risk for STDs acquisition (OR=10.97, 95\% CI: 2.48-99.32). While, vaginal practice represents protection $(\mathrm{OR}=0.36$, 95\% CI: 0.16-0.78). This could be explained, good proportion of STDs found among our patients did not need vaginal intercourse to transmit (scabies and pediculosis). As regard non-vaginal sexual practice (oral, coitus interfemoris and anal) there has been some suggestion that women may be used this practice as means of contraception or it may be a way to remain a technical virgin. Gillmore et al. (1999) stated that vaginal sex is the single most common form $(80.0 \%)$ of sexual intercourse. Oral sex has become a common feature of sexual practice, while, anal sex, as a regular part of married sexuality remains relatively rare. However, non-vaginal sex was more common in short-term and extramarital relationships. About $60.0 \%$ of females report having experienced oral sex, rates of oral sex were comparable for formerly married women. Also, $20.0 \%$ of females report having anal sex at sometime in their lives and about $10.0 \%$ of women reported having anal sex in the past year (Laumann et al., 1992). This represents a large number of women potentially at risk of contracting HIV and other rectally transmitted STDs (Gillmore et al., 1999). As regard frequency of sexual intercourse per week, $56.7 \%$ and $67.8 \%$ of STD patients and control group respectively had 1-2 time intercourse per week $(\mathrm{OR}=0.62,95 \%$ CI: 0.32-1.19). While, $24.4 \%$ and $20.0 \%$ of STD patients and controls respectively had $\geq 3$ time intercourse per week $(\mathrm{OR}=1.29,95 \% \mathrm{CI}$ : $0.60-2.78$ ), this might be explained, $85.6 \%$ of control group were married i.e. more chance to make sexual intercourse. Laumann et al. (1994) reported that about one third of females had vaginal intercourse 2 to 3 times a week. As regard number of 
sexual partners in last 3 months, there was one sexual partner among $90.0 \%$ of STD patients versus $87.8 \%$ among controls $(\mathrm{OR}=1.52$, 95\% CI: 0.57-4.12). Of particular note, all married females of controls had only one sexual partner; Leigh et al. (1993) and Laumann et al. (1994) supported our results. On the other hand, there were two or more partners for $4.4 \%$ of the STD patients versus $0.0 \%$ for controls. This was in consistent with Brunham and Ronald (1991); Binson et al. (1993); Laumann et al. (1994) and Latkin et al. (1994) who reported multiple sexual partners in the last 3 months. Regarding number of lifetime sexual partners, $28.9 \%$ and $4.4 \%$ of STD patients and controls respectively had twolifetime sexual partner $(\mathrm{OR}=8.73,95 \%$, ECL: $2.80-35.76)$. While, $12.2 \%$ and $3.3 \%$ of STD patients and controls respectively had $\geq 3$ lifetime sexual partners $(\mathrm{OR}=4.04$, 95\% ECL: 1.01-23.19). This was in accordance to Gottlieb et al. (2002) and Xu et al. (2002). As regard exchange sex for money/gifts, $23.3 \%$ and $3.3 \%$ of STD patients and controls respectively exchange sex for money/gifts $(\mathrm{OR}=8.83$, 95\% ECL: 2.46-47.59). This was in accordance with Carael et al. (1991); Latkin et al. (1994); Keersmaekers \& Meheus (1998); Ryan et al. (1998); Aral \& Holmes (1999) and Abdullah et al. (2002) who reported 2.0\%$63.0 \%$. Commercial sex has been most common in settings characterized by poverty and social disintegration and it has clearly a major role in the epidemiology of STDs in many developing countries (Keersmaekers \& Meheus, 1998 and Aral \& Holmes, 1999).

As regard partner use of condom (table 5), $75.6 \%, 21.1 \%$ and $3.3 \%$ of our STD patient's partners never, sometimes and ever used condom, respectively. On the other hand, $84.4 \%, 15.6 \%$ and $0.0 \%$ of controls never, sometimes and ever used condom, respectively $(\mathrm{OR}=0.57,95 \% \mathrm{CI}$ : $0.25-1.27 ; 1.45,95 \%$ CI: $0.64-3.33$ and undefined, respectively). This could be explained, in developing countries where prevalence of condom use is generally low (Gertig et al., 1997), condom is not a popular method neither for contraception nor protection, as in Egypt. In this study, it is used mostly by husbands already have STDs, or their wife's have, or as a female request who do not want get pregnant or by individuals who do not want their sexual partners get pregnant in their casual relationships. Kegeles (1988) cleared that female over-estimating the resistance and negative attitude that males have about condom use. Also, Overby and Kegeles (1994) showed that females often feel that they have little or no risk of acquiring STDs. Moreover, Guttmacher et al. (1995) cleared that embarrassment about purchasing condoms may be a particular obstacle for females. Aral and Holmes (1999) stated that use of condom diminished over the duration of a relationship and a major concern, however, is the belief that partners, particularly steady partners, would view the request to use a condom as indicating a lack of trust. Conversely, if the request for used is made by the male, the female may assume he is dating outside the relationship. Our results were concord by Potter and Anderson (1993); Binson et al. (1993); Zenilman et al. (1995); Berman \& Hein (1999); Radcliffe et al. (2001); Abdullah et al. (2002) and Dimitry-Abraham et al. (2003). Potter and Anderson (1993) found that $31.0 \%$ of their women's partners used condoms. Also, Dimitry-Abraham et al. (2003) claimed that $22.6 \%$ of their sample used condom. As regard previous infection with STDs, we reported that $23.3 \%$ and $4.4 \%$ of STD patients and controls respectively had previous STDs infection $(\mathrm{OR}=6.54, \quad 95 \%$ ECL: 2.05-27.19). Gottlieb et al. (2003) found similar risk. While, early consultation for diagnosis and treatment not found among $17.8 \%$ and $8.9 \%$ of STD patients and controls, respectively ( $\mathrm{OR}=2.22,95 \% \mathrm{CI}$ : 0.83-6.04). Laga (1995) and Mohebbi (2005) stated that in many countries STDs treatment for females is seen in the most stigmatizing terms, while, unmarried females are too ashamed to access care, where needed treatment can obtained. Aral \& Holmes (1999); Aral \& Wasserheit (1999) and Mohebbi (2005) stated that data suggested that the stigma concerning STDs may act as a barrier to prompt health care seeking or perhaps related to issues of confidentiality 
or seeking to care symptoms through selftreatment. Thus, females may bear silently the symptoms of genital infections without seeking any health care (Ryan et al., 1998). Moreover, females were not informed about STDs symptoms, Barbin et al. (1995) found that $90.0 \%$ of females had untreated symptoms such as discharge and irritation that warned care but which the females accepted as normal. Adler (1996) and Ryan et al. (1998) emphasized the importance of tracing the contacts of STDs patients and the integration of STD control services into health facilities that women use. These facilities include primary health care centers, general hospitals outpatient clinics, maternal and child health centers and family planning centers. Where a broader concern for reproductive tract infections may be preferable than the more narrow focus on STDs, because the former creates less of a stigma and reflects a more comprehensive approach to women's needs for reproductive health services. On the other hand, compliance with therapy for STDs not found among $23.8 \%$ and $0.0 \%$ of STD patients and controls, respectively. This was in accordance with Brookoff (1994) and Aral \& Wasserheit (1999). Studies suggest that extra efforts on the part of providers can greatly improve compliance. Having convenient and effective treatment regimens can help (Friedman \& Litt 1987 and Haddix et al., 1995). Lastly, regarding partner referral, $60.0 \%$ and $23.3 \%$ of our STD patients and controls respectively not referred their partners (OR=4.93, 95\% CI: 2.47 9.92). This could be explained, casual relationships, STDs stigma, self-treatment or confidentiality (Aral and Wasserheit, 1999).

As regard religious obligation (table 6), 90.0\% of STD patients were not religiously obliged versus $41.1 \%$ of the controls (OR=12.89, 95\% CI: 5.43-31.50). This was confirmed by Bearman \& Bruckner (2001) and Abdullah et al. (2002). Religious obligation is important in abstain from sex until marriage. In Egypt, religious and cultural norms forbid premarital and extramarital sex, they are completely unaccepted for women. On the other hand, smoking was found among $18.9 \%$ and $4.4 \%$ of STD patients and controls, respectively $(\mathrm{OR}=5.01,95 \% \mathrm{CI}$ : 1.53-21.19). This was in accordance with Abdullah et al. (2002). Also, drugs and/or alcohol dependency were reported among $13.3 \%$ and $2.2 \%$ of STD patients and controls, respectively ( $\mathrm{OR}=6.77,95 \%$ ECL: 1.43-63.57). This was in consistent with Zenilman et al. (1994); Abdullah et al. (2002); Crosby et al. (2003) and David \& Tang (2003). These researchers concluded that alcohol and drugs were associated with risky sexual behaviour and would increase the risk for acquiring STDs. Exclusion of disinhibeted mentally ill patient was useful in excluding drug addicts with dual diagnosis. The exclusion covered axis I only, so history of detention or adjudication were found among $6.7 \%$ and $1.1 \%$ of STD patients and controls, respectively $(\mathrm{OR}=$ 6.36, 95\% ECL: 0.74-295.63). This was confirmed by Crosby et al. (2003) and David \& Tang (2003) who showed that adjudication increase the risk for STDs acquisition.

In this study (table 7), 16 (17.8\%) and $3(3.3 \%)$ of our STD patients and controls respectively had a history of pregnancy wastage, with a statistically significant difference $(\mathrm{P}=0.001)$. This was in consistent with Schulz et al. (1986). Regarding ectopic pregnancy, 7 (7.8\%) and 1 (1.1\%) of STD patients and controls respectively had a history of ectopic pregnancy, with a statistically significant difference $(\mathrm{P}=0.029)$. Regarding history of maternal infection, $11(12.2 \%)$ and $3(3.3 \%)$ of STD patients and controls respectively had a positive history, with a statistically significant difference $(\mathrm{P}=0.025)$. This was in consistent with Plummer et al. (1987). Regarding history of PID, 17 (18.9\%) and 4 (4.4\%) of STD patients and controls respectively had a positive history, with a statistically significant difference $(\mathrm{P}=0.002)$. This was in consistent with Frost et al. (1987) and Berman \& Hein (1999). Regarding history of infertility, 8 (8.9\%) and 2 (2.2\%) of STD patients and controls respectively had a positive history, with a statistically significant difference $(\mathrm{P}=0.050)$. STDs and PID can lead to infertility in women due to post infection tubal obstruction. Rate of bilateral tubal 
obstruction is 3 times higher in Africa than in the world, the most important infections are chlamydia and gonorrhoea (Mabey et al., 1985 and Meheus \& De Schryver, 1991). Lastly, a history of complications among infants, were found among 5 (5.6\%) and $1(1.1 \%)$ of STD patients and controls respectively, with a non-statistically significant difference $(\mathrm{P}=0.096)$. This was in accordance with Datta et al. (1988).

In this study (Table 8), practice with symptomatic partner found among 20.8\% and $43.2 \%$ of married and unmarried (divorced or widow) STD patients respectively, the difference was statistically significant $(\mathrm{P}=0.021)$. Also, $11.3 \%$ and $48.7 \%$ of married and unmarried STD patients practiced when they were symptomatic, the difference was statistically significant $(\mathrm{P}=0.000)$. These figures and previously mentioned figures could be explained, lower figures among married because of trust and care among married couples. While, higher figures among divorced and widow represent casual relationships and/or exchange sex for money or gifts. At the same time, $13.2 \%$ and $37.8 \%$ of our STD patients who had previous infections with STDs were married and unmarried respectively, the difference was statistically significant $(\mathrm{P}=0.006)$. This could be explained, sexual relationships for unmarried females were casual or commercial sex with high risk for STDs acquisition. As regard type of sexual practice of married and unmarried females, we claimed that $92.4 \%$ of married STD patients their type of sexual practice was vaginal. Laumann et al. (1994) confirmed our result and said that vaginal intercourse is the most common form $(80.0 \%)$ of the sexual expression among married couples. On the other hand, $40.5 \%$ of unmarried STD patients their type of sexual practice was non-vaginal and this could be explained, as a method of contraception, casual sex with no trust or low price commercial sex. As regard partner use of condom, $92.4 \%$ of married STD patients their partner's never used condom. While, $40.5 \%$ of unmarried STD patients their partner's sometimes used condom. Regarding number of sexual partners in the last 3 months, $98.1 \%$ and
$78.4 \%$ of our STD patients who had one partner were married and unmarried, respectively. Also, $1.9 \%$ and $8.1 \%$ of STD patients who had $\geq 2$ partners were married and unmarried, respectively. Hunt (1974) said that divorced women had a median of 4 partners per year. Also, our results revealed that $88.6 \%$ and $16.2 \%$ of STD patients who had only one-lifetime sexual partners were married and unmarried, respectively. While, $7.6 \%$ and $59.5 \%$ of those who had 2 lifetime sexual partners were married and unmarried, respectively. Lastly, $3.8 \%$ and $24.3 \%$ of those who had $\geq$ 3 sexual partners were married and unmarried, respectively. All previously mentioned differences were statistically significant. These results could be explained, widow and divorced women with no free regular sexual partner tend to look for casual and commercial sex i.e. increase number of lifetime sexual partners. Lastly, $1.9 \%$ and $54.1 \%$ of our married and unmarried STD patients make sex for money or gifts respectively, the difference was statistically significant. These results are understood as married patients have a free and regular sexual partner.

It could be concluded that STDs are an important health and social problem. Unskilled occupation, divorce and live in shared house are important risk markers. Practice when symptomatic and premarital sex are important sexual behaviour risk factors. Also, no partner referral is an important health care behaviour risk factor. Lastly, drugs and/or alcohol use and no religious obligation are the most important life style risks markers. Identification of these risks will help in prevention of STDs. It could be recommended that more work should be carried out on big number of population to understand the true epidemiology and situation of STDs in Egypt and to doubling of efforts to address vulnerable and high-risk groups. Also, the need for a strong national STD prevention and control strategy, tracing the contacts of STDs patients, the integration of STDs control services into health facilities that women use and a comprehensive approach to women's needs for reproductive health services. 
Table (1): Distribution of STDs among the studied female sample.

\begin{tabular}{|l|c|c|}
\hline \multicolumn{1}{|c|}{ Type of STDs } & No. $(\mathbf{n = 9 0 )}$ & \% \\
\hline Candidiasis & 32 & 35.6 \\
\hline Genital warts (GW) & 9 & 10.0 \\
\hline Genital scabies & 9 & 10.0 \\
\hline Bacterial vaginosis (BV) & 8 & 8.9 \\
\hline Pelvic inflammatory disease (PID) & 7 & 7.8 \\
\hline Genital herpes (GH) & 6 & 6.7 \\
\hline Trichomoniasis & 6 & 6.7 \\
\hline Mixed vaginitis & 6 & 6.7 \\
\hline Molluscum contagiosum (MC) & 4 & 4.4 \\
\hline Pediculosis pubis & 3 & 3.3 \\
\hline Gonococcal cervicitis & 3 & 3.3 \\
\hline Syphilis & 2 & 2.2 \\
\hline Non-gonococcal cervicitis & 2 & 2.2 \\
\hline
\end{tabular}

Table (2): Distribution of STD patients and control group according to their sociodemographic risk factors.

\begin{tabular}{|c|c|c|c|c|c|}
\hline \multirow{2}{*}{ Sociodemographic risk factors } & \multicolumn{2}{|c|}{ STD patients } & \multicolumn{2}{|c|}{ Controls } & \multirow{2}{*}{ OR $(95 \%$ CI $)$} \\
\hline & No. & $\%$ & No. & $\%$ & \\
\hline \multicolumn{6}{|l|}{ Educational level: } \\
\hline Illiterate, read \& write & 64 & 71.1 & 43 & 47.8 & $1.94(1.04-3.63)$ \\
\hline Elementary & 18 & 20.0 & 29 & 32.2 & $0.53(0.25-1.09)$ \\
\hline Secondary \& university & 8 & 8.9 & 18 & 20.0 & $2.12(0.54-8.66)$ \\
\hline \multicolumn{6}{|l|}{ Occupation Level: } \\
\hline Unskilled & 72 & 80.0 & 52 & 57.8 & $2.92(1.43-6.01)$ \\
\hline Semi-skilled \& skilled & 14 & 15.6 & 25 & 27.8 & $0.48(0.22-1.06)$ \\
\hline Professional & 4 & 4.4 & 13 & 14.4 & $0.28(0.07-0.96)$ \\
\hline \multicolumn{6}{|l|}{ Social class: } \\
\hline Low & 68 & 75.5 & 48 & 53.3 & $1.86(0.99-3.50)$ \\
\hline Middle & 16 & 17.8 & 27 & 30.0 & $0.50(0.23-1.08)$ \\
\hline High & 6 & 6.7 & 15 & 16.7 & $0.42(0.14-1.27)$ \\
\hline \multicolumn{6}{|l|}{ Residence status: } \\
\hline Shared house \& WC & 67 & 74.4 & 18 & 20.0 & $11.62(5.48-25.11)$ \\
\hline Independent house \& WC & 23 & 25.6 & 72 & 80.0 & $0.09(0.04-0.18)$ \\
\hline
\end{tabular}


Table (3): Distribution of STD patients and control group according to their gynaecological and reproductive history risk factors.

\begin{tabular}{|c|c|c|c|c|c|}
\hline \multirow{2}{*}{$\begin{array}{c}\text { Gynaecological \& reproductive } \\
\text { history risk factors }\end{array}$} & \multicolumn{2}{|c|}{ STD patients } & \multicolumn{2}{|c|}{ Controls } & \multirow[b]{2}{*}{ OR $(95 \% \mathrm{CI})$} \\
\hline & No. & $\%$ & No. & $\%$ & \\
\hline \multicolumn{6}{|l|}{ Marital status: } \\
\hline Married & 53 & 58.9 & 77 & 85.6 & $0.24(0.11-0.53)$ \\
\hline Unmarried: & 37 & 41.1 & 13 & 14.4 & $4.13(1.90-9.10)$ \\
\hline Divorced & 28 & 31.1 & 9 & 10.0 & $4.06(1.68-10.06)$ \\
\hline Widow & 9 & 10.0 & 4 & 4.4 & $2.39(0.64-9.64)$ \\
\hline \multicolumn{6}{|l|}{ Age at menarche: } \\
\hline$<13$ years & 54 & 60.0 & 41 & 45.6 & $1.79(0.95-3.39)$ \\
\hline$\geq 13$ years & 36 & 40.0 & 49 & 54.4 & \\
\hline \multicolumn{6}{|l|}{ Age at marriage: } \\
\hline$<20$ years & 23 & 25.6 & 16 & 17.8 & $1.95(0.73-4.24)$ \\
\hline 20-25 years & 46 & 51.1 & 52 & 57.8 & $0.76(0.41-1.43)$ \\
\hline$\geq 26$ years & 21 & 23.3 & 22 & 24.4 & $0.94(0.45-1.97)$ \\
\hline \multicolumn{5}{|c|}{ Time between sexual maturation and } & $1.76(0.92-3.38)$ \\
\hline Age at first pregnancy: & $\mathrm{n}=86$ & & $\mathrm{n}=88$ & & \\
\hline$<20$ years & 19 & 22.1 & 14 & 15.9 & $1.50(0.65-3.45)$ \\
\hline $20-25$ years & 39 & 45.3 & 55 & 62.5 & $0.50(0.26-0.95)$ \\
\hline$>26$ years & 28 & 32.6 & 19 & 21.6 & $1.75(0.84-3.66)$ \\
\hline Number of lifetime pregnancies: & $\mathrm{n}=82$ & & $\mathrm{n}=88$ & & \\
\hline 0 & 4 & 4.9 & 2 & 2.3 & $2.12(0.32-17.20)$ \\
\hline $1-2$ & 41 & 50.0 & 56 & 63.6 & $0.57(0.30-1.10)$ \\
\hline$\geq 3$ & 37 & 45.1 & 30 & 34.1 & $1.59(0.82-3.10)$ \\
\hline $\begin{array}{l}\text { Currently pregnant: } \\
\text { Yes }\end{array}$ & 5 & 5.6 & 13 & 14.4 & $0.35(0.10-1.11)$ \\
\hline Current contraceptive use: & & & & & \\
\hline Yes: & 46 & 51.1 & 40 & 44.4 & $1.31(0.70-2.45)$ \\
\hline Intra uterine device (IUD) & 34 & 37.8 & 29 & 32.2 & $1.28(0.66-2.47)$ \\
\hline Oral contraceptive & 12 & 13.3 & 11 & 12.2 & $1.10(0.42-2.88)$ \\
\hline $\begin{array}{l}\text { Vaginal douching use: } \\
\text { Yes }\end{array}$ & 37 & 41.1 & 8 & 8.9 & $7.16(2.91-18.15)$ \\
\hline
\end{tabular}


Table (4): Distribution of STD patients and control group according to their sexual behaviour risk factors.

\begin{tabular}{|c|c|c|c|c|c|}
\hline \multirow{2}{*}{ Sexual behaviour risk factors } & \multicolumn{2}{|c|}{ STD patients } & \multicolumn{2}{|c|}{ Controls } & \multirow{2}{*}{ OR $(95 \% \mathrm{CI})$} \\
\hline & No. & $\%$ & No. & $\%$ & \\
\hline $\begin{array}{l}\text { Age at initiating sexual practice: } \\
\leq 20 \text { years } \\
21-25 \text { years } \\
\geq 26 \text { years }\end{array}$ & $\begin{array}{l}32 \\
51 \\
7\end{array}$ & $\begin{array}{c}35.5 \\
56.7 \\
7.8\end{array}$ & $\begin{array}{l}19 \\
46 \\
25\end{array}$ & $\begin{array}{l}21.1 \\
51.1 \\
27.8\end{array}$ & $\begin{array}{l}2.06(1.01-4.24) \\
1.25(0.67-2.35) \\
0.22(0.08-0.28)\end{array}$ \\
\hline $\begin{array}{l}\text { Premarital sexual practice: } \\
\text { Yes }\end{array}$ & 51 & 56.7 & 8 & 8.9 & $13.40(5.46-34.10)$ \\
\hline $\begin{array}{l}\text { Practice with symptomatic partner: } \\
\text { Yes }\end{array}$ & 27 & 30.0 & 6 & 6.7 & $6.00(2.23-18.69)^{*}$ \\
\hline $\begin{array}{l}\text { Practice when symptomatic: } \\
\text { Yes }\end{array}$ & 24 & 26.7 & 3 & 3.3 & $10.55(2.98-56.37) *$ \\
\hline $\begin{array}{l}\text { Type of sexual practice: } \\
\text { No practice } \\
\text { Vaginal } \\
\text { Non vaginal (oral/anal/interfemoris) } \\
\end{array}$ & $\begin{array}{l}10 \\
61 \\
19\end{array}$ & $\begin{array}{l}11.1 \\
67.8 \\
21.1\end{array}$ & $\begin{array}{l}11 \\
77 \\
2 \\
\end{array}$ & $\begin{array}{c}12.2 \\
85.6 \\
2.2\end{array}$ & $\begin{array}{c}0.90(0.33-2.43) \\
0.36(0.16-0.78) \\
10.97(2.48-99.32)^{*}\end{array}$ \\
\hline $\begin{array}{l}\text { Frequency of intercourse/week: } \\
0 \\
1-2 \\
\geq 3 \\
\end{array}$ & $\begin{array}{l}17 \\
51 \\
22\end{array}$ & $\begin{array}{l}18.9 \\
56.7 \\
24.4\end{array}$ & $\begin{array}{l}11 \\
61 \\
18\end{array}$ & $\begin{array}{l}12.2 \\
67.8 \\
20.0\end{array}$ & $\begin{array}{l}1.67(0.69-4.12) \\
0.62(0.32-1.19) \\
1.29(0.60-2.78)\end{array}$ \\
\hline $\begin{array}{l}\text { No. of sexual partners in last } 3 \text { months: } \\
0 \\
1 \\
\geq 2 \\
\end{array}$ & $\begin{array}{c}5 \\
81 \\
4 \\
\end{array}$ & $\begin{array}{c}5.6 \\
90.0 \\
4.4 \\
\end{array}$ & $\begin{array}{l}11 \\
79 \\
0\end{array}$ & $\begin{array}{c}12.2 \\
87.8 \\
0.0 \\
\end{array}$ & $\begin{array}{c}0.35(0.09-1.11)^{*} \\
1.52(0.57-4.12) \\
--------\cdot * *\end{array}$ \\
\hline $\begin{array}{l}\text { No. of lifetime sexual partners: } \\
1 \\
2 \\
\geq 3 \\
\end{array}$ & $\begin{array}{l}53 \\
26 \\
11 \\
\end{array}$ & $\begin{array}{l}58.9 \\
28.9 \\
12.2\end{array}$ & $\begin{array}{c}83 \\
4 \\
3\end{array}$ & $\begin{array}{l}92.3 \\
4.4 \\
3.3 \\
\end{array}$ & $\begin{array}{c}0.12(0.05-0.31) \\
8.73(2.80-35.76)^{*} \\
4.04(1.01-23-19)^{*}\end{array}$ \\
\hline $\begin{array}{l}\text { Exchange sex for money and/or gifts: } \\
\text { Yes }\end{array}$ & 21 & 23.3 & 3 & 3.3 & $8.83(2.46-47.59)^{*}$ \\
\hline
\end{tabular}

* Exact confidence limits

** Undefined: odds ratio cannot be calculated due to control group $=0$. 
Table (5): Distribution of STD patients and control group according to their health care behaviour risk factors.

\begin{tabular}{|c|c|c|c|c|c|}
\hline \multirow[t]{2}{*}{ Health care behaviour risk factors } & \multicolumn{2}{|c|}{ STD patients } & \multicolumn{2}{|c|}{ Controls } & \multirow{2}{*}{ OR (95\% CI) } \\
\hline & No. & $\%$ & No. & $\%$ & \\
\hline \multicolumn{6}{|l|}{ Your partner use condom: } \\
\hline Never & 68 & 75.6 & 76 & 84.4 & $0.57(0.25-1.27)$ \\
\hline Sometimes & 19 & 21.1 & 14 & 15.6 & $1.45(0.64-3.33)$ \\
\hline Ever & 3 & 3.3 & 0 & 0.0 & ---------------** \\
\hline \multicolumn{6}{|l|}{ Previous infection with STDs: } \\
\hline Yes & 21 & 23.3 & 4 & 4.4 & $6.45(2.05-27.19) *$ \\
\hline No & 69 & 76.7 & 86 & 95.6 & $0.15(0.04-0.49)^{*}$ \\
\hline \multicolumn{6}{|l|}{$\begin{array}{l}\text { Early consultation for diagnosis } \\
\text { and treatment of STDs: }\end{array}$} \\
\hline Yes & 74 & 82.2 & 82 & 91.1 & $0.45(0.17-1.20)$ \\
\hline No & 16 & 17.8 & 8 & 8.9 & $2.22(0.83-6.04)$ \\
\hline Compliance with STDs therapy: & $\mathrm{n}=21$ & & $\mathrm{n}=4$ & & \\
\hline Yes & 16 & 76.2 & 4 & 100.0 & $0.00(0.00-6.63) *$ \\
\hline No & 5 & 23.8 & 0 & 0.0 & ----------------** \\
\hline \multicolumn{6}{|l|}{ Partner referral for therapy: } \\
\hline Yes & 36 & 40.0 & 69 & 76.7 & $0.20(0.10-0.41)$ \\
\hline No & 54 & 60.0 & 21 & 23.3 & $4.93(2.47-9.92)$ \\
\hline
\end{tabular}

* Exact confidence limits

** Undefined: odds ratio cannot be calculated due to control group $=0$

Table (6): Distribution of STD patients and control group according to their life style markers.

\begin{tabular}{|l|c|c|c|c|c|}
\hline \multirow{2}{*}{ Life style risk markers } & \multicolumn{2}{|c|}{ STD patients } & \multicolumn{2}{c|}{ Controls } & \multirow{2}{*}{ OR (95\% CI) } \\
\cline { 2 - 5 } & No. & \% & No. & \% & \\
\hline Religious obliged: & & & & & \\
$\quad$ Yes & 9 & 10.0 & 53 & 58.9 & $0.08(0.03-0.18)$ \\
$\quad$ No & 81 & 90.0 & 37 & 41.1 & $12.89(5.43-31.50)$ \\
\hline $\begin{array}{l}\text { Smoking habit: } \\
\text { Yes }\end{array}$ & 17 & 18.9 & 4 & 4.4 & $5.01(1.53-21.19)$ \\
$\quad$ No & 73 & 81.1 & 86 & 95.6 & $0.20(0.05-0.65)^{*}$ \\
\hline Drugs and/or alcohol dependency: & 12 & 13.3 & 2 & 2.2 & $6.77(1.43-63.57)^{*}$ \\
$\quad$ Yes & 78 & 86.7 & 88 & 97.8 & $0.15(0.02-0.70)^{*}$ \\
$\quad$ No & & & & & \\
History of detention /adjudication: & 6 & 6.7 & 1 & 1.1 & $6.36(0.74-295.63)^{*}$ \\
$\quad$ Yes & 84 & 93.3 & 89 & 98.9 & $0.16(0.00-1.35)^{*}$ \\
$\quad$ No & & & & & \\
\hline
\end{tabular}

* Exact confidence limits 
Table (7): Distribution of STD patients and control group according to STDs impacts.

\begin{tabular}{|l|c|c|c|c|c|c|}
\hline \multicolumn{1}{|c|}{ STDs impacts } & \multicolumn{2}{|c|}{ STD patients } & \multicolumn{2}{c|}{ Controls } & \multirow{2}{*}{$\boldsymbol{\chi}^{\mathbf{2}}$} & $\begin{array}{c}\text { P- } \\
\text { Value }\end{array}$ \\
\cline { 2 - 7 } & No. & $\boldsymbol{\%}$ & No. & $\boldsymbol{\%}$ & & \\
\hline $\begin{array}{l}\text { History of pregnancy wastage: } \\
\text { Yes }\end{array}$ & 16 & 17.8 & 3 & 3.3 & 9.94 & 0.001 \\
\hline $\begin{array}{l}\text { History of ectopic pregnancy: } \\
\text { Yes }\end{array}$ & 7 & 7.8 & 1 & 1.1 & 4.71 & 0.029 \\
\hline $\begin{array}{l}\text { History of maternal infections: } \\
\text { Yes }\end{array}$ & 11 & 12.2 & 3 & 3.3 & 4.96 & 0.025 \\
\hline $\begin{array}{l}\text { History of PID: } \\
\text { Yes }\end{array}$ & 17 & 18.9 & 4 & 4.4 & 9.11 & 0.002 \\
\hline $\begin{array}{l}\text { Infertility: } \\
\text { Yes }\end{array}$ & 8 & 8.9 & 2 & 2.2 & 3.81 & 0.050 \\
\hline $\begin{array}{l}\text { Complications among infants: } \\
\text { Yes }\end{array}$ & 5 & 5.6 & 1 & 1.1 & 2.76 & 0.096 \\
\hline
\end{tabular}

Table (8): Distribution of STD patients' marital status by some sexual and health care behaviour risk factors.

\begin{tabular}{|c|c|c|c|c|c|c|}
\hline \multirow{3}{*}{ Sexual and health care behaviour risk factors } & \multicolumn{4}{|c|}{ STD patients $(\mathrm{n}=90)$} & \multirow{3}{*}{$\chi^{2}$} & \multirow{3}{*}{$\begin{array}{c}\text { P- } \\
\text { Value }\end{array}$} \\
\hline & \multicolumn{2}{|c|}{$\begin{array}{c}\text { Married } \\
(\mathrm{n}=53)\end{array}$} & \multicolumn{2}{|c|}{$\begin{array}{c}\text { Unmarried } \\
(n=37)\end{array}$} & & \\
\hline & No. & $\%$ & No. & $\%$ & & \\
\hline $\begin{array}{l}\text { Age at initiating sexual practice: } \\
\quad \leq 20 \\
21-25 \\
\geq 26\end{array}$ & $\begin{array}{c}17 \\
31 \\
5 \\
\end{array}$ & $\begin{array}{c}32.1 \\
58.5 \\
9.4 \\
\end{array}$ & $\begin{array}{c}15 \\
20 \\
2 \\
\end{array}$ & $\begin{array}{c}40.5 \\
54.1 \\
5.4 \\
\end{array}$ & $\begin{array}{l}0.68 \\
0.17 \\
0.49 \\
\end{array}$ & $\begin{array}{l}0.409 \\
0.676 \\
0.482 \\
\end{array}$ \\
\hline $\begin{array}{l}\text { Practice with symptomatic partner: } \\
\text { Yes }\end{array}$ & 11 & 20.8 & 16 & 43.2 & 5.25 & 0.021 \\
\hline $\begin{array}{l}\text { Practice when symptomatic: } \\
\text { Yes }\end{array}$ & 6 & 11.3 & 18 & 48.7 & 15.53 & 0.000 \\
\hline $\begin{array}{l}\text { Previous infection with STDs: } \\
\text { Yes }\end{array}$ & 7 & 13.2 & 14 & 37.8 & 7.39 & 0.006 \\
\hline 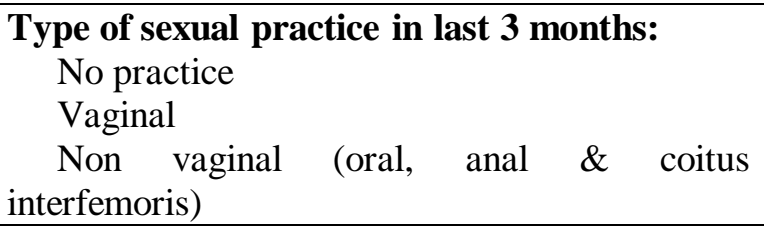 & $\begin{array}{c}0 \\
49 \\
4\end{array}$ & $\begin{array}{c}0.0 \\
92.4 \\
7.6\end{array}$ & $\begin{array}{l}10 \\
12 \\
15\end{array}$ & $\begin{array}{l}27.1 \\
32.4 \\
40.5\end{array}$ & $\begin{array}{l}16.11 \\
35.94 \\
14.24\end{array}$ & $\begin{array}{l}0.000 \\
0.000 \\
0.000\end{array}$ \\
\hline $\begin{array}{l}\text { Partner use of condom: } \\
\text { Never } \\
\text { Sometimes } \\
\text { Ever }\end{array}$ & $\begin{array}{c}49 \\
4 \\
0\end{array}$ & $\begin{array}{c}92.4 \\
7.6 \\
0.0\end{array}$ & $\begin{array}{c}19 \\
15 \\
3\end{array}$ & $\begin{array}{c}51.4 \\
40.5 \\
8.1\end{array}$ & $\begin{array}{c}19.93 \\
14.24 \\
4.45\end{array}$ & $\begin{array}{l}0.000 \\
0.000 \\
0.034\end{array}$ \\
\hline $\begin{array}{l}\text { Number of sexual partners in last } 3 \text { months: } \\
0 \\
1 \\
\geq 2 \\
\end{array}$ & $\begin{array}{c}0 \\
52 \\
1 \\
\end{array}$ & $\begin{array}{c}0.0 \\
98.1 \\
1.9 \\
\end{array}$ & $\begin{array}{c}5 \\
29 \\
3 \\
\end{array}$ & $\begin{array}{c}13.5 \\
78.4 \\
8.1 \\
\end{array}$ & $\begin{array}{l}7.58 \\
9.43 \\
1.99 \\
\end{array}$ & $\begin{array}{l}0.005 \\
0.002 \\
0.158 \\
\end{array}$ \\
\hline $\begin{array}{l}\text { Number of lifetime sexual partners: } \\
1 \\
2 \\
\geq 3\end{array}$ & $\begin{array}{c}47 \\
4 \\
2\end{array}$ & $\begin{array}{c}88.6 \\
7.6 \\
3.8\end{array}$ & $\begin{array}{c}6 \\
22 \\
9\end{array}$ & $\begin{array}{l}16.2 \\
59.5 \\
24.3\end{array}$ & $\begin{array}{c}47.26 \\
28.58 \\
8.58\end{array}$ & $\begin{array}{l}0.000 \\
0.000 \\
0.003\end{array}$ \\
\hline $\begin{array}{l}\text { Exchange sex for money and/or gifts: } \\
\text { Yes }\end{array}$ & 1 & 1.9 & 20 & 54.1 & 33.15 & 0.000 \\
\hline
\end{tabular}




\section{References}

1. Abdullah AS, Fielding R, Hedley AJ and Luk YK (2002): Risk factors for sexually transmitted diseases and casual sex among Chinese patients attending sexually transmitted disease clinics in Hong Kong. Sex Trans Dis, 29 (6): 360-5.

2. Adler MW (1996): Sexually transmitted diseases control in developing countries. Genitourinary Medicine, 72: 83-8.

3. Amo J, Gonzalez $\mathbf{C}$, Losana J, Clavo $\mathbf{P}$, Muoz L, Ballesteros J, Garcia-Saiz A, Belza MJ, Ortiz M, Menendez B, Romero J and Bolumar $F$ (2005): Influence of age and geographical origin in the prevalence high risk human papilloma virus in migrant female sex workers in Spain. Sex Trans Infec, 81: 79-84.

4. Aral SO and Holmes KK (1999): Social and behavioural determinants of the epidemiology of STDs: Industrialized and developing countries. In: Sexually transmitted diseases, $3^{\text {rd. }}$ ed., Holmes KK, Mardh PA, Sparling PF, Lemon SM, Stamm WE, Piot P, Wasserheit JN (eds.), McGraw-Hill, New York.

5. Aral SO and Wasserheit JN (1999): STDrelated health care seeking and health service delivery. In: Sexually transmitted diseases, $3^{\text {rd. }}$ ed., Holmes KK, Sparling PF, Moroh PA, Lemon SM, Stamm WE, Piot P, Wasserheit JN (eds.), McGraw-Hill, New York.

6. Barbin L, David T and Hook I (1995): Reproductive tract infections and abortion among adolescent girls in rural Nigeria. Lancet, 345: 300-4.

7. Bearman PS and Bruckner H (2001): Promising the future virginity pledges and first intercourse. A J Sociology, 106: 859912.

8. Behets F, Edward W and Hook I (2001): Sex transmitted infections and associated sociodemograohic and behavioral factors in women seeking primary care suggest Madagascar's vulnerability to rapid HIV spread.J Trop Med Int Health,6 (3): 202-11.

9. Behets $F$, Leegaard $M$, Cotch $M$, and Gibbs S (2002): Laboratory diagnosis of sexually transmitted infections in women with genital discharge in Madagascar: Implications for primary care. Int J STDs \& AIDS, 13: 606-11.

10. Berman SM and Hein $K$ (1999): Adolescents and STDs. In: Sexually transmitted diseases, $3^{\text {rd. }}$ ed., Holmes KK, Mardh PA, Sparling PF, Lemon SM,
Stamm WE, Piot P, Wasserheit JN (eds.), McGraw-Hill, New York.

11. Bernitsky LG and Roy JB (1986): Male infertility and genitourinary infections. Infertility, 9: 129-44.

12. Binson D, Kessler $A$ and Ostrow D (1993): Multiple sexual partners among young adults in high-risk cities. Fam Plann Perspect, 25 (6): 268-72.

13. Blankgart D, Robert $\mathbf{N}$, Nathan $\mathbf{S}$ and Yun Y (1999): Sexually transmitted infections in young pregnant women in Bangui, Central African Republic. Int $\mathbf{J}$ STDs \& AIDS, 10: 609-14.

14. Bogaerts J, Paul R and Martin H (2001): Sexually transmitted infections among married women in Dhaka, Bangladesh: Unexpected high prevalence of herpes simplex type 2 infection. Sex Trans Infec, 77: 114-9.

15. Braddic MR, Moore $\mathbf{P}$ and Wang $\mathbf{H}$ (1991): Cofactors in male-female transmission of HIV-1. J Infec Dis, 163: 233-9.

16. Brookoff D (1994): Compliance with doxycycline therapy for out patient treat of pelvic inflammatory disease. So Med J, 87: 1088-92.

17. Brooks GF, Batel JS and Morse SA (1998): Principles of diagnostic medical microbiology. In: Jawetz, Melnick and Adelberg's Medical Microbiology, $21^{\text {st. }}$ ed., Appelton \& Lange.

18. Brunham RC and Ronald AR (1991): Epidemiology of sexually transmitted diseases in developing countries. In: Research issues in human behaviour and sexually transmitted diseases in the AIDS era, Wasserheit JN, Aral SO and Holmes KK (eds.), Am Soc Microbiol, Washington, DC.

19. Brunham RC and Embree JE (1992): Sexually transmitted diseases: Current and future dimensions of the problem in the third world. In: Reproductive tract infections, Germain A, Holmes KK, Piot P and Wasserheit JN (eds.), Plenum Press, New York.

20. Carael M, Newton $R$, Cook $P$ and Howard M (1991): Overview and selected findings of sexual behaviour surveys. AIDS, 5: S65-S8.

21. Centers for Disease Control and Prevention (1995): Trend in sexual risk behaviour among high school studentsUnited States, 1990, 1991 and 1993. MMWR, 44: 124-8. 
22. Claeys P, Cohen V, Monvalya $\mathbf{K}$ and Simmonds P (2001): Sexually transmitted infections and reproductive health in Azerbaijan. Sex Trans Dis, 28 (7): 372-8.

23. Clift S, Anemona A, Watson $D$ and Kanga $Z$ (2003): Variations of HIV and STI prevalence within communities neighboring New Gold Mines in Tanzania: Importance for intervention design. Sex Trans Infec, 79: 307-12.

24. Crosby RA, Diclemente RJ, Wingood G and Levine $D$ (2003): Adjudication history and African American adolescents risk for acquiring STDs: An explorer analysis. Sex Trans Dis, 30 (8): 634-8.

25. Csonka GW (1990): Scabies. In: Sexually transmitted diseases. A textbook of genitourinary medicine, Csonka GW and Oates JK (eds.), Bailliere Tindall.

26. Dan M, Sadan O, Glezerman M, Raveh $D$ and Samra $Z$ (2003): Prevalence and risk factors for herpes simplex virus type 2 infection among pregnant women in Israel. Sex Trans Dis, 30 (11): 835-8.

27. Datta $\mathbf{P}$, Laga $M$ and Plummer FA (1988): Infection and disease after perinatal exposure to Chlamydia trachomatis in Nairobi, Kenya. J Infec Dis, 158: 524-8.

28. David N and Tang A (2003): Sexually transmitted infection in a young offenders institution in the UK. Int J STDs \& AIDS, 14 (8): 513-7.

29. De Schryver A and Meheus A (1990): Epidemiology of sexually transmitted diseases: The global picture. Bulletin WHO, 68: 639-54.

30. Dimitry-Abraham C, Cande-Glez CJ, Cruz-Valdez A, Sanchez-Zamorano L, Hernandez-Marquez $C$ and LazcanoPonce E (2003): Sexual and demographic risk factors for herpes simplex virus type 2 according to schooling level among Mexican Youths. Sex Trans Dis, 30 (7): 549-55.

31. Esquivel CA, Baker $L$ and Sewftel $\mathbf{H}$ (2003): Prevalence of Chlamydia trachomatis infection in registered female sex workers in northen Mexico. Sex Trans Dis, 30 (3): 195-8.

32. Evans BA, Tasker $T$ and MacRae KD (1993): Risk profiles for genital infection in women.Genitourinary Medicine 69:257-61.

33. First MB, Spitzer RI, Gibbon M, and Williams JBW (1994) : Structured clinical Interview for DSM IV Axis I disorders. patient edition (SCID-P) version 2. New York State Psychiatric Institute Biometric Research.
34. Forrest JD (1993): Timing of reproductive life stages. Obst \& Gyn, 82: 105-9.

35. Friedman IM and Litt IL (1987): Adolescents compliance with therapeutic regimens: Psychological and social aspects and intervention. J Adol Health Care, 8: 526.

36. Frost E, Collet M, Reniers J, Leclerc A, Jvanoff B and Meheus A (1987): Importance of chlamydial antibodies in acute salpingitis in Central Africa. Genitourinary Medicine, 63: 176-8.

37. Garcia LS and Bruckner DA (2001): Diagnostic medical parasitology, $3^{\text {rd. }}$ ed.: 549-52.

38. Garg S, Hana T, John, L and Suthon V (2002): Reproductive morbidity in an Indian urban slum: Need for health action. Sex Trans Infec, 78: 68-9.

39. Gerbase A, Rowley JT, and Mertens TE (1998): Global epidemiology of sexually transmitted diseases. Lancet, 251 (53): 2-4.

40. Gertig DM, Hodge M, Razak M, Beyrer C and Nelson K (1997): Risk factors for sexually transmitted diseases among women attending family planning clinics in Dar-es-Salaam, Tanzania. Genitourinary Medicine, 73 (1): 39-43.

41. Gillmore MR, Schwartz P and Givic D (1999): The social context of sexuality: The case of the United States. In: Sexually transmitted diseases, $3^{\text {rd. }}$ ed., Holmes KK, Mardh PA, Sparling PF, Lemon SM, Stamm WE, Piot P, Wasserheit JN (eds.), McGraw-Hill, New York.

42. Gottlieb SL, Douglas JM, Schmid DS, Bolan G, Iausta M, Malotte CK, Zenilman J, Foster M, Baron AE, Steiner JF, Peterman TA and Kamb ML (2002): Seroprevalence and correlates of herpes simplex virus type 2 infection in five sexually transmitted disease clinics. J Infec Dis, 185: 1381-9.

43. Graham C (1994): AIDS and the adolescent. Int J STDs \& AIDS, 5: 305-9.

44. Guttmacher S, Jack D, Betsy F and Ella M (1995): Gender differences in attitudes and use of condom availability programs among sexually active students in New York City public high schools. J Am Med Women Assoc, 50: 99-104.

45. Haddix AC, Zdolsek B, Hellberge D and Nilsson $S$ (1995): The cost effectiveness of azithromycin for Chlamydia tracomatis infections in women. Sex Trans Dis, 22: 274-7.

46. Hunt M (1974): Sexual behaviour in the 1970s. Play Boy Press, Chicago. 
47. Keersmackers K and Meheus A (1998): Epidemiology of sexually transmitted infections and AIDS in developing countries. In: Sexually transmitted infections and AIDS in the tropics, Arya PP and Hart CA (eds.).

48. Kegeles SM (1988): Sexually active adolescents and condoms: Changes over one year in knowledge, attitudes and use. AJPH, 78: 460-5.

49. Kirkman $R$ and Chantler $E$ (1993): Contraception and prevention of sexually transmitted diseases. BMB, 49 (1): 171-81.

50. Laga M (1995): STD control for HIV prevention, it works. Lancet, 346: 518-21.

51. Laga M, Diallo MO and Buve A (1994): Interrelationship of sexually transmitted diseases and HIV: Where are we now? AIDS, 8 (Suppl. 1): S119-S24.

52. Laga M, Nzila N and Goeman J (1995): The interrelationship of sexually transmitted diseases and HIV infection: Implications for the control of both epidemics in Africa. AIDS, 5 (Suppl. 1): S55-S63.

53. Latkin C, Mandell W, Oziemkowska M, Vlahov D and Celentano D (1994): The relationships between sexual behaviour, alcohol use and personal network characteristics among injecting drug users in Baltimore, Maryland. Sex Trans Dis, 2: 161-7.

54. Laumann EO, Robert $\mathbf{T}$ and John $\mathbf{H}$ (1994): The social organization of sexuality: Sexual practices in the US Chicago, Chicago University Press.

55. Leigh BC, Stall $\mathbf{R}$ and Alliegre MB (1994): Sexual behaviour of American adolescents: Results from a US National Survey. J Adol Health, 15: 117-22.

56. Lopez-Velez R, Huerga $H$ and Torrent's MC (2003): Infectious diseases in immigrants from the perspective of a tropical medicine referral unit. Am J Trop Med Hyg, 69 (1): 115-21.

57. Mabey DCW, Ogbaselassie G, Robertson JN Heckels JE and Ward ME (1985): Chlamydial and gonococcal serology in women with tubal occlusion compared with pregnant controls. Bulletin WHO, 63: 1107-13.

58. Mak RP, Van Renterghem $L$ and Traen A (2005): Chlamydia trachomatis in female sex workers in Belgium: 1998-2003. Sex Trans Infec, 81: 89-90.

59. Meheus A and De Schryver A (1991): Sexually transmitted diseases in the third world. In: Recent advances in sexually transmitted diseases and AIDS, Harris JRW and Forster SM (eds.), Churchill Livingstone.

60. Mohebbi MR (2005): Female sex workers and fear of stigmatization. Sex Trans Infec, 81: $180-1$.

61. Nugent RP, Krohn MA and Hillier S (1991): Reliability of diagnosing bacterial vaginosis is improved by a standardized method of Gram stain interpretation. J Clin Microbiol, 29: 297-301.

62. Oriel JD and Walker PG (1990): Genital papilloma virus infections. In: Sexually transmitted diseases. A textbook of genitourinary medicine. Csonka GW and Oates JK (eds.), Bailliere Tindall.

63. Osoba AO (1981): Sexually transmitted diseases in tropical Africa: A review of the present situation. Br J Ven Dis, 57: 89-94.

64. Overby KJ and Kegeles SM (1994): The impact of AIDS on an urban population of high-risk female minority adolescents: Implications for intervention. $\mathbf{J}$ Adol Health, 15: 216-22.

65. Plummer FA, Laga $M$ and Prunham RC (1987): Postpartum upper genital tract infections in Nairobi, Kenya: Epidemiology, aetiology and risk factors. J Infec Dis, 156: 92-8.

66. Potter LP and Anderson JE (1993): Patterns of condom use and sexual behaviour among never married women. Sex Trans Dis, 20: 201-7.

67. Radcliffe KW, Ahmad S, Gilleran G and Ross JD (2001): Demographic and behavioural profile of adults infected with chlamydia: A case control study. Sex Trans Infec, 77: 265-70.

68. Richert CA, Peterman TA, Zaidi AA, Ransom RL and Wroten JE (1993): A method for identifying persons at high risk for sexually transmitted infections: Opportunity for targeting intervention. AJPH, 83(4): 520-4.

69. Rizk M, Ammar M, Elawady S and Ahmed $M$ (2003): Factors affecting prevalence of bacterial vaginosis in nonpregnant women. The New Egypt J Med, 28 (2): 80-5.

70. Ryan CA, Suprasongsin C and Becker D (1998): Explosive spread of HIV-1 and sexually transmitted diseases in Cambodia. Lancet, 351: 1175-7.

71. Schulz KF, Cates $W$ and O'Mara $P$ (1986): A synopsis of the problems in Africa of syphilis and gonorrhoea during pregnancy. Afr J STDs, 2: 56-60.

72. Shoubnikova M Henberg D, Nilsson $\mathbf{S}$ and Mardh PA (1997): Contraceptive use 
in women with bacterial vaginosis. $\mathrm{Br} \mathrm{J}$ Obst Gyn, 104: 1391-7.

73. Smith GL, Greenap $\mathbf{R}$ and Takafaji $\mathbf{E}$ (1987): Circumcision as a risk factor for urethritis in racial groups. AJPH, 77 (4): 452-4.

74. Thurow L (1996): The future of capitalism: How today's economics forces shape tomorrow's world. Boston, Morrow.

75. Wasserheit JN (1992): Epidemiological synergy: Interrelation between human immunodeficiency virus infection and other sexually transmitted diseases. Sex Trans Dis, 19: 61-43.

76. Wasserheit JN and Holmes KK (1992): Reproductive tract infections: Challenges for international health policy, programs and research. In: Reproductive tract infection: Global impact and priorities for women's reproductive health, Germain A, Holmes KK, Piot P and Wasserheit JN (eds.), Plenum Press, New York.

77. WHO (2001): Report on the regional consultation to strengthen STD prevention and care strategies in the countries of the Eastern Mediterranean Region. WHO Regional Office for the Eastern Mediterranean.

78. WHO (2002): Progress report on acquired immunodeficiency syndrome (AIDS) in the Eastern Mediterranean Region. 49 Session of the Regional Committee for the Eastern Mediterranean.

79. Wong W, Pambis JA, Hernendez MT, Chaw JK and Klausner JD (2003): Prevalence of sexually transmitted diseases among Latino immigrant day laborers in an urban setting-San Francisco. Sex Trans Dis, 30 (8): 661-3.

80. Xu F, Schillinger M, Stermberg R, Johnson $F$ and Adve $J$ (2002): Seroprevalence and co-infection with herpes simplex virus type I and type II in the United States 1988-1999. J Infec Dis, 185(8): 1019-24.

81. Zelnik M and Kantner J (1980): Sexual activity, contraceptive use and pregnancy among metropolitan-area teenagers: 19711979. Fam Plann Perspect, 12: 230-3.

82. Zenilman JM, Hook EW $3^{\text {rd. }}$, Shepherd M, Smith P, Rompalo AM and Celantano DD (1994): Alcohol and other substance use in STD clinic patients: Relationships with STDs and prevalent infection. Sex Trans Dis, 21 (4): 220-5.

83. Zenilman JM, Weisman CS, Rompalo AM, Ellish N, Upchurch DM, Hook EW $3^{\text {rd. }}$ and Celentano D (1995): Condom use to prevent incident STDs: The validity of self-reported condom use. Sex Trans Dis, 22 (1): 15-21.

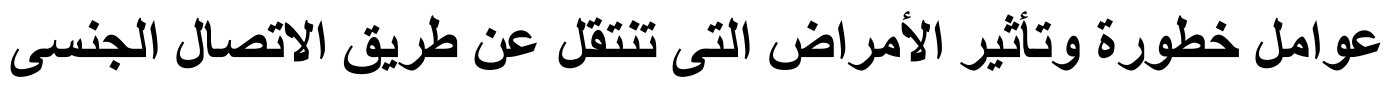




\section{فى الإناث البالغات فى القاهرة}

\section{عصام عبد المنعم المصيلحى- حامد عمر خليفهـ خالد محمد عبد الله ـ فيصل عبد

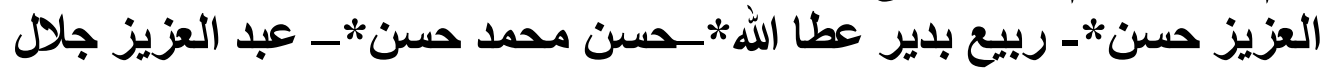

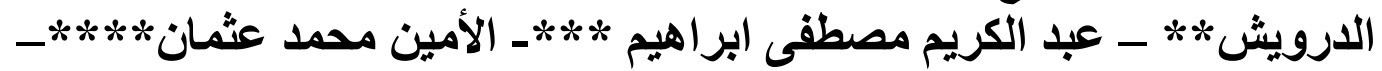

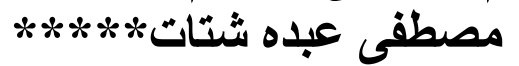

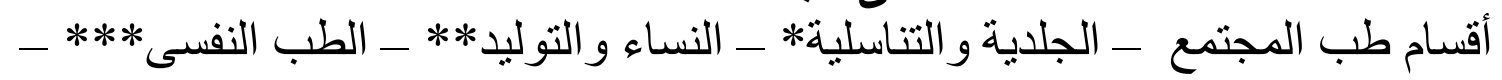
الميكروبيولوجى

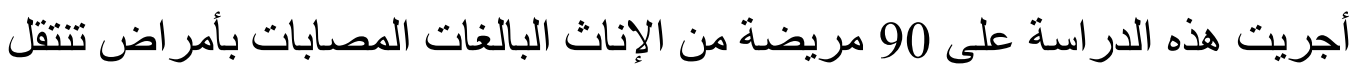

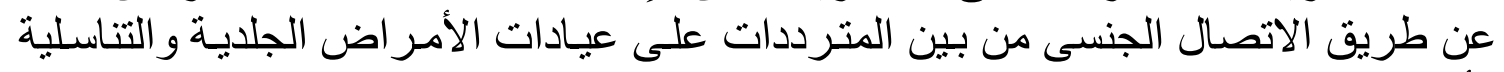

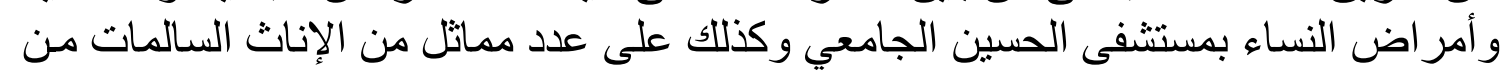

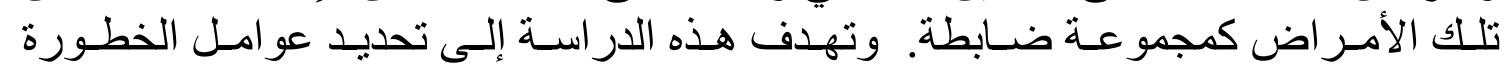

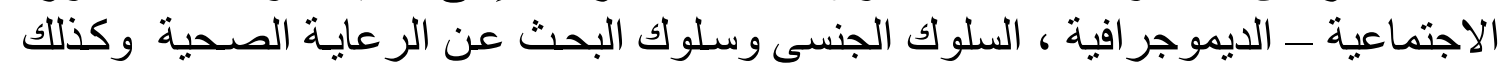

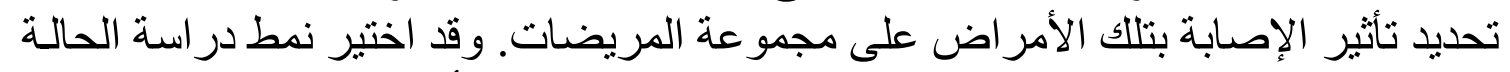

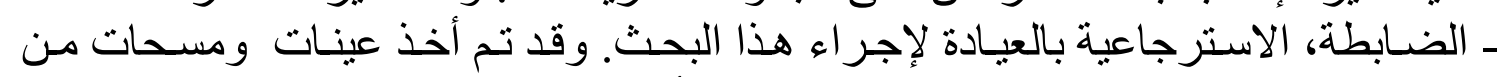

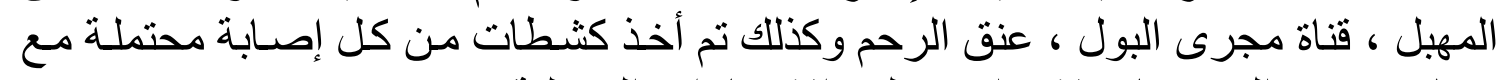

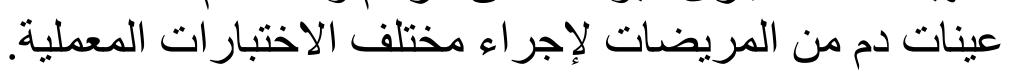

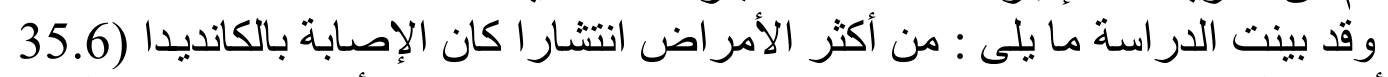

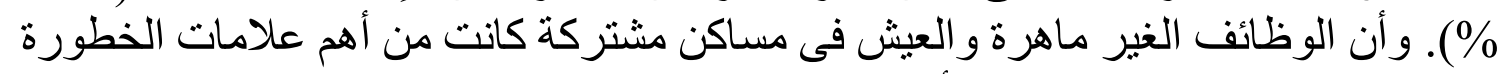

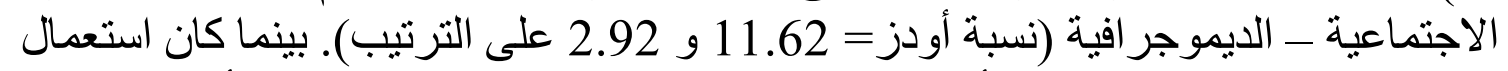

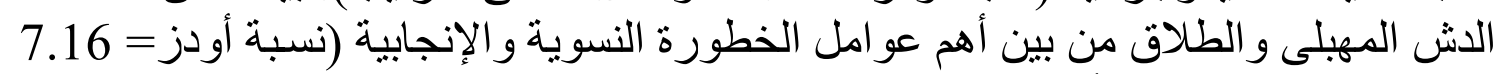

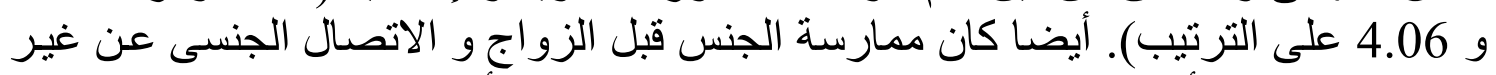
طريق المهبل من أهم عو امل الخطورة للسلوك الجنسئ الجنى (نسبة أودز =

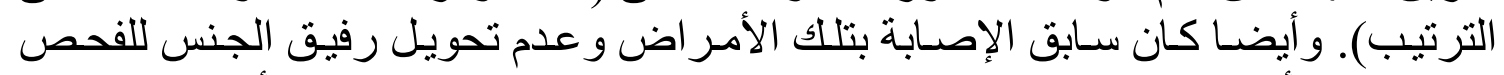

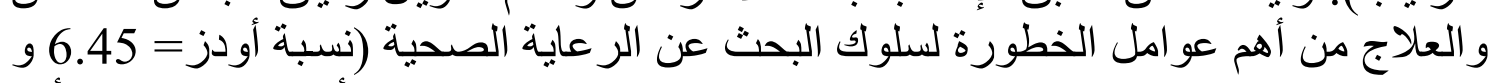

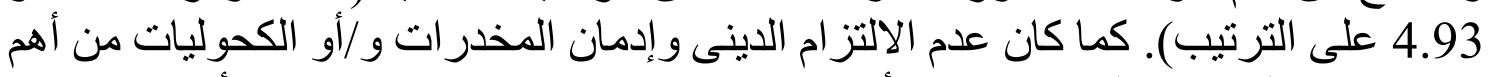

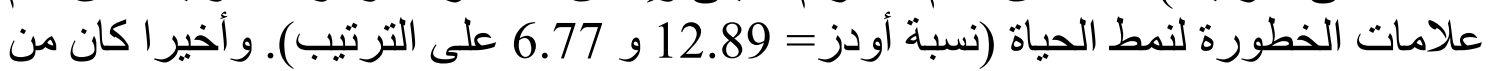

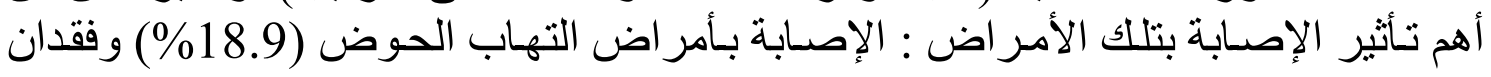

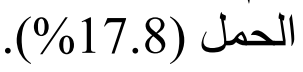

